\title{
Detection of Latent HIV-1 Infection and Drug Resistant Mutation Testing in Nepal: HIV-1 env V3 DNA Sequence and RT Gene (M184V) Mutation
}

\author{
Rupendra Shrestha ${ }^{1,2 *}$, Sundar Khadka1,2, Susbin Raj Wagle ${ }^{1,2}$, Alisha Sapkota ${ }^{1,2}$ \\ 1Department of Laboratory Medicine, Nobel College, Sinamangal, Kathmandu, Nepal. \\ ${ }^{2}$ Center for Molecular Dynamics Nepal (CMDN), Thapathali-11, Kathmandu, Nepal.
}

\begin{abstract}
HIV-1 resistance to antiretroviral therapy (ART) is a crucial issue, despite various effective drugs are available for the treatment. Although the viral RNA is suppressed below the detection limit $(<50 \mathrm{copies} / \mathrm{ml})$ with the use of potent antiviral drugs, the mutation can be archived in the cellular reservoir as proviral DNA. The detection of proviral DNA and mutation screening in HIV 1 RNA for genotypic resistance is the sole basis for monitoring the effectiveness of ART. Our study aim to access the extent of latent HIV infections by detecting env V3 DNA and also testing of M184V (meth184val; ATG - GTG substitution at $184^{\text {th }}$ codon) specific mutations in HIV-1 RT gene to monitor the effectiveness of ART. The HIV-1 env V3 DNA sequence was amplified using multiple upstream and downstream primes to show the latent HIV infections, whereas polymerase chain reactionrestriction fragment digestion assay (PCR-RFDA) was used for testing M184V mutation in HIV-1 RT gene. In the study, out of 15 HIV infected patient blood samples, 12 shows amplification of env V3 DNA, confirming the latent HIV infections while 3 were negative for env V3 DNA. HIV-1 RT gene tested for M184V mutation in all 15 samples showed wild type after analysis using PCR-RFDA. After digestion with CviAII, three bands were observed in wild type whereas in mutant only two bands. Although the study shows negative for the M184V resistance mutation, screening of various panels of drug resistance mutations should be performed in recently infected HIV1 patients for planning the effective ART strategy. The data is not enough to compare the overall scenario of the Nepal thus warrant urgency for large scale study with standard genotypic tools.
\end{abstract}

Keywords: HIV-1, Antiretroviral Therapy, Resistance Mutation, env V3 DNA, RT gene.

*Corresponding Author

E-mail: dph.rupendra@gmail.com

\section{Introduction}

HIV/AIDS is the gradually increasing global epidemic threat with an estimated 36.7 million HIV positive people worldwide. Among them 5.1 million people are in Asia including 3,00,000 newly infected and 1,80,000 AIDS-related deaths occurred in Asia per year [1]. Till date 39,249 people are estimated to be living with HIV in Nepal [2].

The HIV epidemic has changed due to use of antiretroviral therapies (ARTs) that suppress the HIV-1 RNA load in plasma below the detection limit $(<50$ copies $/ \mathrm{ml})$. However, lifelong ART is necessary for patients with latent HIV infections due to decrease in level of CD4+ lymphocytes [3, 4]. The decrease in level of CD4+ T cells caused by HIV infection leads into AIDS and cause opportunistic infections, like Pneumocystis Carinii pneumonia and Kaposi's sarcoma [5]. More than $50 \%$ of the worldwide epidemic are due to HIV-1 subtype C and are prone to genotypic resistance with treatment failure. HIV-1 has a higher rate of replication with lack of $3^{\prime}$ to $5^{\prime}$ proof reading mechanism and highly error-prone to reverse transcriptase [6-8]. The selection of drug specific resistance mutation in viral genome is due to treatment failure and those mutations may be archived into the cellular reservoir (Proviral DNA). Thus, mutations can be detected in proviral DNA even if HIV RNA is below detection limit [9]. HIV1 resistance to ART is a major problem which is due to suboptimum treatment and transmission of resistant variant at the time of infection [10-12].

Resistance mutation is associated with high replicative activities of the viral genome during therapy. Several drugs have been approved for the treatment of HIV-1 infection such as nucleotide and nucleoside reverse transcriptase inhibitors (NRTIs), protease inhibitors (PIs), nonnucleoside RT inhibitors (NNRTIs), and fusion inhibitors. However, drug resistance mutations in HIV-1 remain crucial, even though effective (ART) is available in the global market. One of the commonly associated drug resistance mutations in HIV-1 RT gene is $\mathrm{M} 184 \mathrm{~V}$. The appearance of Lamivudine 
(3TC) resistance mutation, M184I, was found to be transiently proceeded to the outgrowth of M184V substitution [13-15]. The study of the nucleotide sequences of both 3TC-resistant variants shows that M184V (GTG) originates from wild-type Met (ATG) but not from the M184I variant (ATA) [16]. Both variants are generated from the wildtype ATG sequence by transitional substitutions ( $G$ to $A$ for $184 \mathrm{I}$ and $\mathrm{A}$ to $\mathrm{G}$ for $184 \mathrm{~V})$. The $\mathrm{G}$ to A substitution is the type of mutation that most commonly occur during replication of HIV-1 thus M184I appears before M184V [17, 18]. In addition, there have been no systematic studies of HIV-1 resistance mutation in Nepalese population.

Here, we performed the preliminary study of common drug resistance mutation, M184V using a basic molecular tool called PCR-RFDA and assessed the detection of proviral DNA in HIV-1 infected patients with prolonged ART.

\section{Materials and Methods}

\section{Patients counselling and collection of samples}

Individual patient counselling was performed on the background of HIV/AIDs, diagnosis, monitoring, treatment, drug resistant and genotype testing. A questionnaire was performed with regards to drug use, sexual behavior and travel history. 15 samples were collected from HIV-1 infected patients undergoing long term ART commonly with 2-3 NRTIs and 1-2 PIs or an NNRTI for at least 3 - 4 years recruited in sparsha Nepal, sanepa, Kathmandu was included. Out of 15 cases, only two were clinically approved as ART resistance and viral loads of each patients are shown in Table 1. Data were collected as a part of a continuing study of antiretroviral treatment at the time of primary HIV-1 infection, which was approved by the Department of Laboratory Medicine, Research Committee of Nobel College and Chief of Sparsha Nepal.

\section{Extraction of Nucleic Acid}

The nucleic acid extraction procedure was performed in Biosafety cabinet (BSL-2). HIV-1 RNA was extracted using precision QIAamp Viral RNA mini kit (Qiagen, Hilden, Germany) while DNA was extracted using Shine Gene Whole Blood DNA extraction kit (Wuhe Road, Minhang District,
Shanghai, China) as per manufacturer's instructions.

\section{Proviral DNA Detection: Nested PCR Nested PCR for HIV-1 env gene}

The nested PCR was performed in the env V3 DNA sequences of HIV-1 for the amplification using highfidelity Pfu DNA Polymerase. The amplification was performed as described in previous study [19]. The total reaction volume of $20 \mu 1$ containing 1 X PCR buffer, $1.5 \mathrm{mM} \mathrm{MgCl}$, $200 \mu \mathrm{M}$ dNTPs, and $0.25 \mathrm{U}$ of Pfu enzyme and RNase free water. The first round PCR was performed with $0.5 \mu \mathrm{M}$ of upstream primers JA9AE (5'CACAGTACAATGCACACATG-3'), JA9B (5'CACAGTACAATGTACACATG-3'), and downstream primers JA12A (5'GCAATAGAAAAATTCTCCTC-3'), JA12B (5'ACAGTAGAAAAATTCCCCTC-3'). The reaction mixture was incubated at $95^{\circ} \mathrm{C}$ for 15 minutes, $94^{\circ} \mathrm{C}$ for $30 \mathrm{Sec}, 58^{\circ} \mathrm{C}$ for $30 \mathrm{Sec}, 72^{\circ} \mathrm{C}$ for $30 \mathrm{Sec}$ and $72^{\circ} \mathrm{C}$ for 10 minutes, for 35 PCR cycles. $1 \mu$ l of the firstround PCR product was used as template for second-round PCR. Inner upstream primers used were a mixture of $0.33 \mu \mathrm{M}$ each of JA10UB (5'CTGTTAAATGGCAGTCTAGC-3'), JA10UC (5'CTGTTAAATGGTAGTCTAGC-3'), and JA10UG (5'-CTGTTAAATGGCAGTTTAGC-3'). Inner downstream primers used were different for each reaction, namely, $0.33 \mu \mathrm{M}$ each of JA11LAE (5'AATTTCTAGATCCCCTCCTG-3'), JA11LB (5'AATTTCTGGGTCCCCTCCTG-3'), and JA11LC (5' AATTTCTAGGTCCCCTCCTG-3'). The reaction mixture was incubated at $95^{\circ} \mathrm{C}$ for 15 minutes, $94^{\circ} \mathrm{C}$ for $30 \mathrm{Sec}, 50^{\circ} \mathrm{C}$ for $30 \mathrm{Sec}, 72^{\circ} \mathrm{C}$ for $30 \mathrm{Sec}$ and $72^{\circ} \mathrm{C}$ for 10 minutes, for 35 PCR cycles. The final PCR product was resolved in $1.7 \%$ agarose gel electrophoresis and image was captured using gel documentation.

\section{HIV-1 RNA Mutational (M184V) Analysis: PCR-RFDA RT gene amplification: Nested PCR}

The amplification of HIV-1 RT gene was performed using nested primer pairs which were reported in previous study [20]. The isolated HIV-1 RNA was subjected to OneStep RT-PCR (Qiagen, Hilden, Germany). The RT-PCR product was then used as templates for second round PCR. The QIAGEN 
Table 1: Patient's information, ART and genotypic testing in the study population n-15

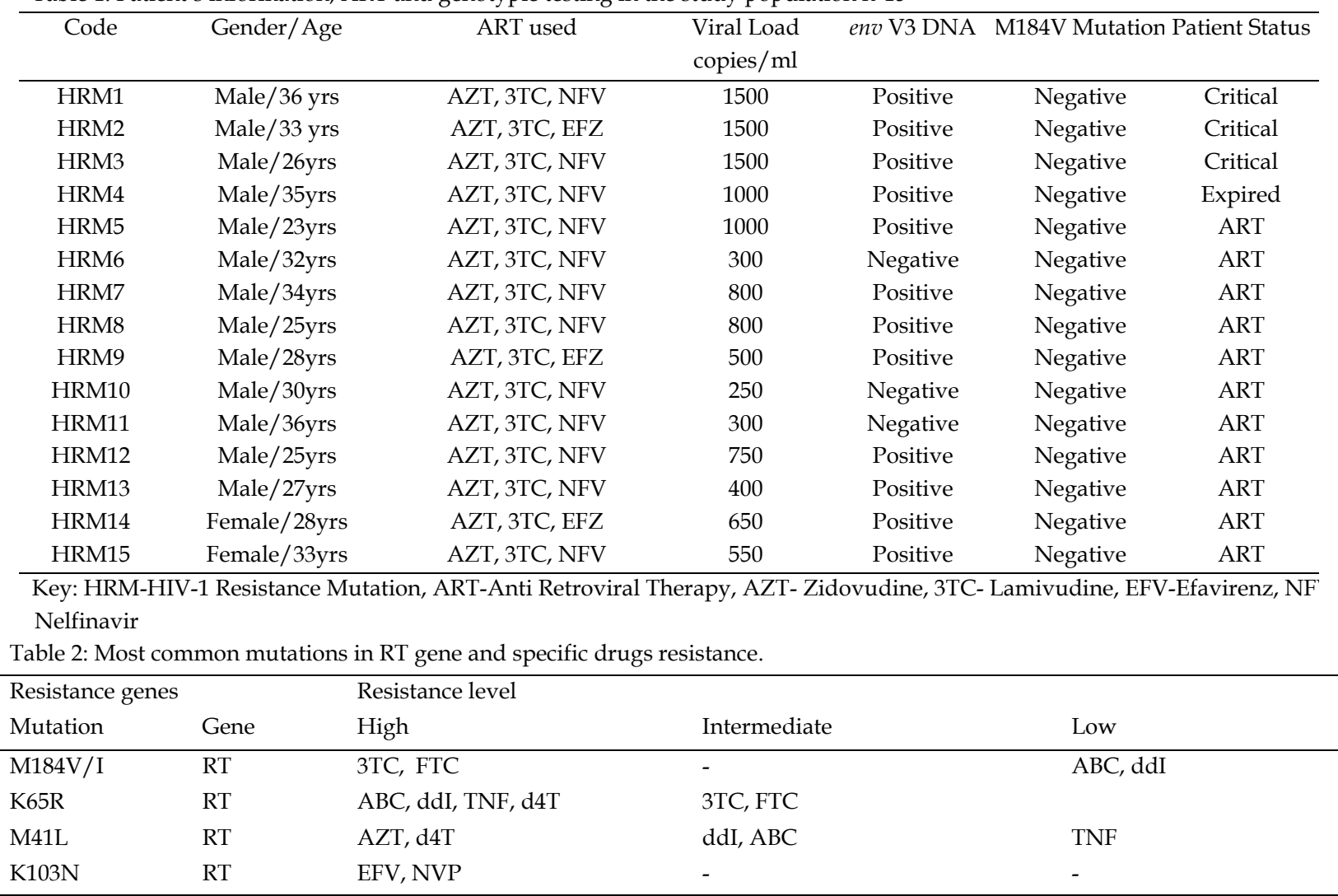

Key: 3TC- Lamivudine, FTC-emtricitabine, AZT- Zidovudine, d4T- Stavudine, EFV-Efavirenz, NVP- Nevirapine, ABC- Abacavi Didanosine, TNF- Tenofovir

OneStep RT-PCR was performed as recommended by the manufacturer. The total volume of $50 \mu \mathrm{l}$ reaction was carried out containing RNase free water, 1x OneStep RT-PCR buffer, $200 \mu \mathrm{M}$ dNTP mix, $0.6 \mu \mathrm{M}$ of each primers A1 (5'AATTTTCCCATTAGCCCTATT-3') and NE1 (5'TATGTCATTGACAGTCCAGCT-3'), $\quad 2 \mu \mathrm{l}$ of OneStep RT-PCR enzyme mix, 5 units RNase inhibitor and $2 \mu \mathrm{g}$ viral RNA for reversetranscriptase gene. The reaction was incubated at $48^{\circ} \mathrm{C}$ for 20 minutes (reverse transcription) followed by $94^{\circ} \mathrm{C}$ for 4 minutes, $94^{\circ} \mathrm{C}$ for $30 \mathrm{Sec}, 52^{\circ} \mathrm{C}$ for 30 Sec, $72^{\circ} \mathrm{C}$ for $30 \mathrm{Sec}$, and $72^{\circ} \mathrm{C}$ for 10 minutes, for 35 PCR cycles. The second round PCR was done by using a QIAGEN master mix with $5 \mu$ of the first RT-PCR product and primers NNA (5'AAGCCAGGAATGGATGGCCCA-3,) and E (5'CCATTTATCAGGATGGAGTTC- $\left.3^{\prime}\right)$. The reaction mixture was incubated at $95^{\circ} \mathrm{C}$ for 15 minutes, $94^{\circ} \mathrm{C}$ for $30 \mathrm{Sec}, 50^{\circ} \mathrm{C}$ for $30 \mathrm{Sec}, 72^{\circ} \mathrm{C}$ for $45 \mathrm{Sec}$ and $72^{\circ} \mathrm{C}$ for 10 minutes, for 30 PCR cycles.

\section{M184V Mutation Testing: Restriction Fragment Digestion Assay (RFDA)}

The amplified RT gene was tested for M184V mutation by digestion approach called RFDA. The RFDA was performed using restriction enzymes CviAII. The total volume of $50 \mu 1$ reaction was performed containing 1 X NEBuffer, 10 units' CviAII restriction enzyme, and $1 \mu \mathrm{g}$ RT-PCR product at $25^{\circ} \mathrm{C}$ for 1 hour. The digested product was resolved in $1.7 \%$ agarose gel electrophoresis and image were captured using gel documentation.

\section{Results}

In the present study, detection of proviral DNA by amplification of env V3 DNA sequences was done by nested PCR while testing of resistance mutation in the HIV-1 RT (MET $184 \mathrm{VAL}$ ) gene was performed by PCR and RFDA. Individual band, resulting from final PCR product and enzyme digested product was compared with ART resistance strain and molecular size marker (100bp). The results are tabulated and is shown in Table 1. 


\section{Identification of env V3 DNA}

The env V3 DNA sequence was analyzed to rule out latent HIV-1 infections. Out of 15 samples amplified for env gene, only 12 of samples show positive for env V3 DNA sequence by nested PCR. The size of the product was $335 \mathrm{bp}$ which was a band of our
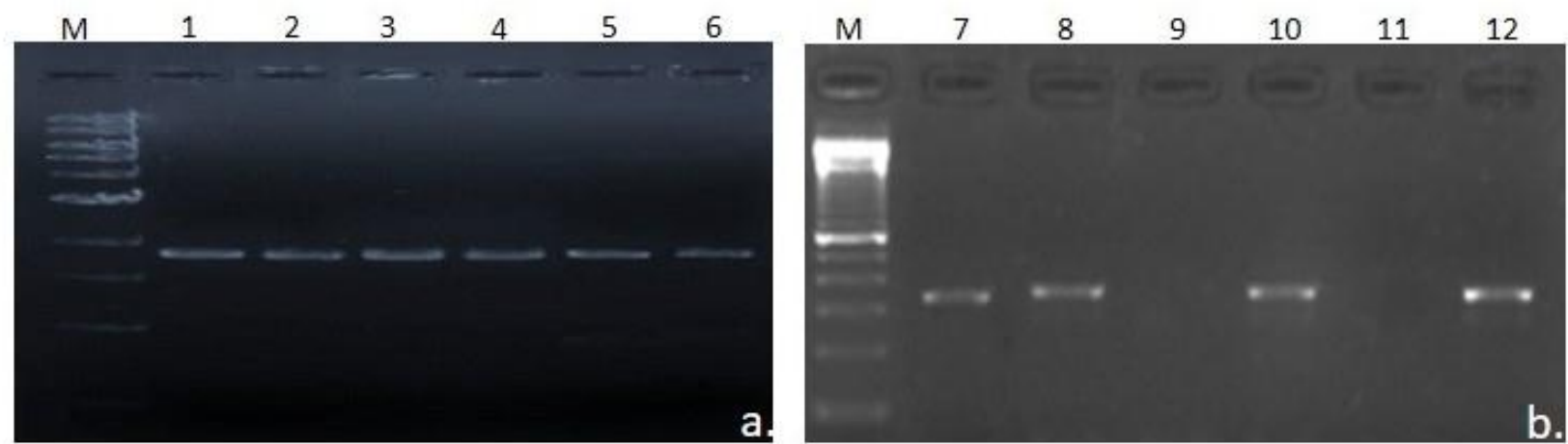

Figure 1: Nested PCR for env V3 DNA sequences. Marker (M) of 100bp was used to compare the molecular weight of amplified product resolved in gel of $1.7 \%$. a) Amplified product with band of interest (335bp) was visualized in all lane 1-6. b) Amplified product was observed only in lane 7, 8, 10, 12 but not in lane 9 and 11. Gel image of 3 positive samples is not shown.

interest and is illustrated in Figure 1 (a \& b). The remaining 3 samples negative for the same gene was reamplified twice showed the similar results. The reason for env gene negative in those three samples might be due to complete elimination of proviral DNA or due to its reduction below the detection limit after prolonged ART.

\section{M184V mutation in HIV-1 RT gene}

HIV-1 RNA was tested for the most common mutation; M184V which emerges in patients using lamivudine (3TC) monotherapy or can be a phenotypic reversion of zidovudine (ZDV). PCRRFDA molecular tool was used for testing the mutation in which gene was amplified by nested PCR and further final product was digested with CviAII restriction endonucleases. In the present study, we tested M184V mutation in 15 samples and all showed wildtype strain. The wildtype strains show three fragment after digestion with band size of $453 \mathrm{bp}, 60 \mathrm{bp}$ and $168 \mathrm{bp}$ are susceptible to 3TC while mutant type have 2 bands with size of $453 \mathrm{bp}$ and $228 \mathrm{bp}$ are considered as 3TC resistance which means the $\mathrm{M} 184 \mathrm{~V}$ resistance mutation was emerged by modification of the 184 restriction site substituting CviAII enzymes. The virtual schematic illustration of Nested PCR and RFDA of both wild type and mutant type is shown in Figure 2 (a \& b).

\section{Discussion}

Early detection of drug resistance mutation in HIV-1 infected patients in developing countries is CNJB, Biotechnology Society of Nepal a big challenge however, can aid clinicians in making proper ART strategy plans. Various molecular tools like real time PCR and sequencing facilities are still lacking. Also, such tools are expensive and less sensitive to minor resistance variants. The development of cheap and sensitive tools to screen resistance mutation can be a breakthrough in the field of molecular biology for low economic countries like Nepal. In the study, we used nested PCR and PCR-RFDA to detect HIV-1 Infections and screen the prevalence of M184V mutation in HIV-1 patients underwent prolong ART. The cheap and sensitive methods for detecting primary infection in infants and latent HIV-1 infection is to identify proviral DNA. The HIV proviral DNA is positive after 28 days while most healthy individuals are accustomed to waiting 3 months for a conclusive result. We performed nested PCR to identify the env V3 DNA sequences in 15 samples, out of which 12 showed positive for proviral DNA. The PCR amplification on 3 negative samples was repeated twice with the same primers for the env V3 DNA but consistently the results were negative. The reason might be a low copy number which is below the detection limit or can be complete elimination of proviral DNA due to prolonged ART. The standard methods for the detection of HIV-1 Proviral DNA are currently lacking and several discordant results are still present in different studies [21]. In the present study, we didn't study for the Nepjol.info/index.php/njb 
A. HIV-1 $R T(\mathrm{M} 184 \mathrm{~V})$ wild type strain

First Round PCR: 777bp

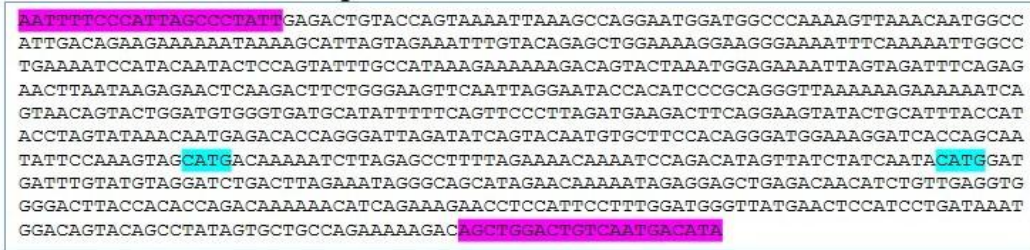

\section{Second Round PCR: $681 \mathrm{bp}$}

AAGCCAGGAATGGATGGCCCAAAAATTAAACAATGGCCATTGACAGAAGAAAAAAATAAAAGCATTAGTAGAAATTTGTAC AGAGCTGGAAAAGAAGGGAAAATTTCAAAAATTGGGCCT GAAAATCCATACAATACTCCAGTATTTGCCATAAAGAAAA AAGACAGTACTAAATGGAGAAAATTAGTAGATTTCAGAGAACTTAATAAGAGAACTCAAGACTTCTGGGAAGTTCAATTA GGAATACCACATCCCGCAGGGTTAAAAAAAGAAAAAATCAGTAACAGTACTGGATGTGGGTGATGCATATTTTTCAGTTCC TAATAMATA ACAACG MACARAMARGAGGGGCTGR CATTCCTTIGGATGGGTTATGAACTCCATCCTGATAAATG

RFDA of second PCR product by CviAII restriction endonuclease

\begin{tabular}{|c|c|c|c|c|}
\hline \multicolumn{3}{|r|}{ CviA } & CriAl & \\
\hline & $453 b p$ & & $60 \mathrm{bp}$ & $168 \mathrm{bp}$ \\
\hline S.N & Ends & Coordinates & Length (bp) & \\
\hline 1 & (LeftEnd)-CviAll & $1-453$ & 453 & \\
\hline 2 & CviAll-CviAll & $454-513$ & 60 & \\
\hline 3 & CviAll-(RightEnd) & $514-681$ & 168 & Note: Line diagram of restrict \\
\hline \multicolumn{5}{|c|}{ B. HIV-1 RT (M184V) mutant type strain } \\
\hline \multicolumn{5}{|c|}{ First Round PCR: 777bp } \\
\hline \multicolumn{5}{|c|}{ 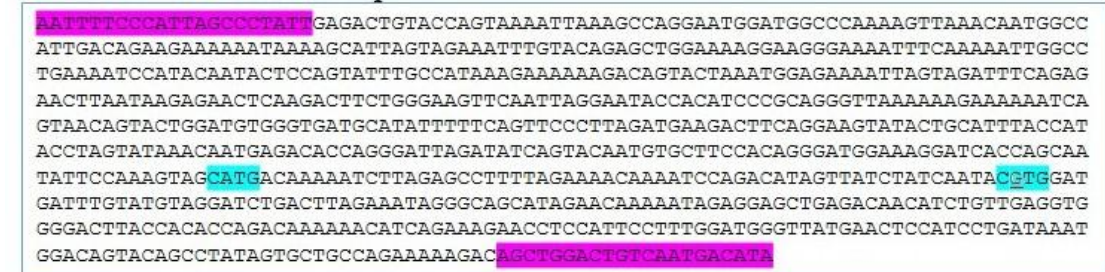 } \\
\hline
\end{tabular}

Second Round PCR: 681bp

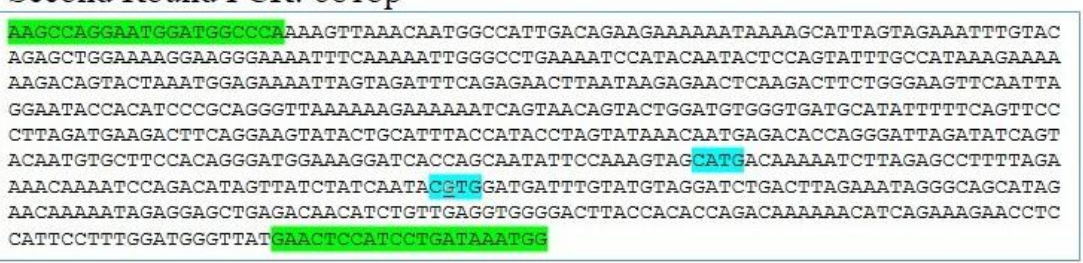

CATG is restriction sites for CviAII. In mutant type only one restriction sites is present due to single nucleotide substitution in another restriction sites.

$$
\begin{aligned}
& 184^{\text {th }} \text { Codon } \\
& \mathrm{ATG} \longrightarrow \mathrm{GTG}
\end{aligned}
$$

CviAII-restriction sites

$5^{\prime} \ldots C^{\top}{ }^{\top} A T$ T G $\ldots 3^{\prime}$

$3^{\prime} \ldots$ G T A C ...

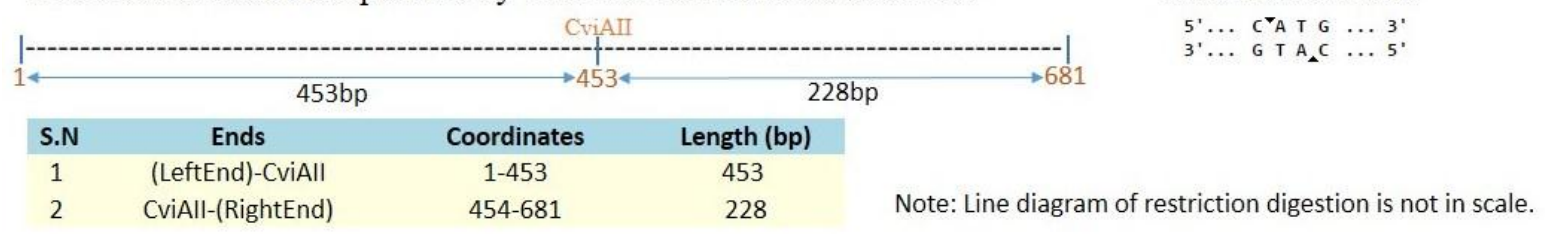

Figure 2: Nested PCR and RFDA for detection of M184V resistance mutation. a) Wildtype stain with three bands of size 453bp, 60bp, 168bp. b) Mutant strain with two bands of size 453bp and 228bp

resistance mutation in $\mathrm{HIV}-1$ proviral DNA. However, the presence of drug resistance mutations in the reservoir of latent HIV-1 provirus and their stability may impact future management and/or treatment possibilities. The presence of latent proviral DNA doesn't indicate the resistance to ART but the specific mutation like
M184V, k65R, M41L and K103N etc. can be detected if the similar mutation is observed in HIV-1 RNA. This is due to retention of mutant from HIV-1 RNA into cDNA due to long term suppressive ART that integrates into host genome. The evolution of drug resistance mutation in globally epidemic HIV-1 is due to suboptimal 
treatment, a point mutation in viral genome and resistance variants leads to incomplete suppression of the viral genome. The development of drug resistance mutation threatens the success of the future therapy regimens. The challenge in treatment of HIV-1 is associated with the development of drug resistance mutation against antiretroviral drugs which can significantly reduce the viral RNA to undetectable levels in plasma [22]. The various resistance mutation pattern has been reported with majorities in both nucleoside reverse transcriptase inhibitors (NRTIs) and non- nucleoside reverse transcriptase inhibitors (NNRTIs) while only a few with NNRTIs and also in minor ratio with protease inhibitors (PI) and 3- class resistance (NRTIs, NNRTIs and PIs). The genotyping of the reverse transcriptase gene sequence revealed that almost $90 \%$ resistance mutation were M184V [23] and such mutation emerges in patients receiving lamivudine (3TC) therapy, but also it could be associated with phenotypic reversion of zidovudine (ZDV) resistance [24]. In the present study, we screened for M184V resistance mutation in HIV-1 infected patients receiving 3TC in combination by PCRRFDA methods. The only wild type strain was found in all the sample analyzed which means the M184V mutation was negative. Our results completely contradict the other reports on M184V. In the study though phenotypic resistance and high viral load were included, M184V mutation was not detected which might be due to numerous reasons like 1) duration of 3TC ART, 2) Possibilities of other mutation like M184I, K65R, etc 3) change in drugs 4) less likely to be technical error. The commonly used drugs by the HIV-1 infected patients in Nepal are AZT, 3TC, EFV and NFV and is shown in Table 1. The high level resistance to 3TC associated with M184V mutation is also resistance to other drugs like FTC, ABC and ddI. In addition to this, resistance to $3 \mathrm{TC}$ is also associated with $\mathrm{K} 65 \mathrm{R}$ mutation and its variant forms but the level of resistance may vary from high-intermediate-low. The most common RT gene mutation and specific drug resistance is shown in Table 2. There are several mutations in genes of HIV-1 associated with resistance to specific drugs [25]. The M184V mutation was detected in lesser than $10 \%$ by allele specific PCR but was consistently negative by standard genotyping [26] While the ratio of mutant and wild type is equal to 50:50 reported by almost half of the laboratories [27]. The prevalence of the M184V mutation is notably higher than that of other mutation [28-30] and is significantly associated with 3TC [31].

The early detection of resistance mutation in HIV-1 infected patients would help to change the treatment regimens susceptible to both Proviral DNA and viral RNA and control measures can be taken to minimize the transmission of resistant variants. An understanding of the molecular mechanism of drug resistance will enable us to develop improved tools for resistance screening.

\section{Conclusion}

In the present study, we set out to identify the HIV1 latent infections by detecting env V3 DNA sequences using nested PCR. In addition to this, the M184V resistance mutation was not observed in the samples analyzed thus indicating as wild type strain. Also, we optimized the PCR-RFDA protocol using CviAII restriction enzymes for the HIV-1 RT strains for mutation testing. This strategy was meant to enhance assay discrimination between the specific drug resistance mutation (mutant allele) and its wild type (wild type allele) using nested primers and CviAII restriction enzymes.

\section{Declaration of interests}

The authors declare that they have no competing interests.

\section{Authors' contributions}

Rupendra came up with the study, frame experimental work and prepared manuscript. All authors have equally involved in completing the research experiment and data compiling. All authors read and approved the final manuscript for publication.

\section{Acknowledgement}

The authors would like to thank the Nobel College for funding the projects and Center for Molecular Dynamics Nepal (CMDN) for providing all the facilities to perform the research experiment. We also like to thank Dr. Sameer M. Dixit, Bhavesh Mishra, Raunak Shrestha, Sulochana Manandhar, and Prajwal Rajbhandari for their valuable discussion and extensive support to make this work done. 


\section{References}

1. Global AIDS Update: UNAIDS Report. Geneva; 2016.

2. Country Progress Report: National Centre for AIDS and STD Control (NCASC). Nepal; 2015.

3. Finzi D, Hermankova M, Pierson T, Carruth LM, Buck C, Chaisson RE, Quinn TC, Chadwick K, Margolick J, Brookmeyer R, Gallant J, Markowitz M, Ho DD, Richman DD, Siliciano RF: Identification of a reservoir for HIV-1 in patients on highly active antiretroviral therapy. Science 1997, 278(5341): 1295-1300.

4. Siliciano JD, Kajdas J, Finzi D, Quinn TC, Chadwick K, Margolick JB, Kovacs C, Gange SJ, Siliciano RF: Long-term follow-up studies confirm the stability of the latent reservoir for HIV-1 in resting CD4+ $\mathrm{T}$ cells. Nature medicine 2003, 9(6): 727-728.

5. Levy JA, Hoffman AD, Kramer SM, Landis JA, Shimabukuro JM, Oshiro LS: Isolation of lymphocytopathic retroviruses from San Francisco patients with AIDS. Science 1984, 225(4664): 840-842.

6. Ho DD, Neumann AU, Perelson AS, Chen W, Leonard JM, Markowitz M: Rapid turnover of plasma virions and CD4 lymphocytes in HIV-1 infection. Nature 1995, 373(6510): 123-126.

7. Roberts JD, Bebenek K, Kunkel TA: The accuracy of reverse transcriptase from HIV-1. Science 1988, 242(4882): 1171-1173.

8. Preston BD, Poiesz BJ, Loeb LA: Fidelity of HIV-1 reverse transcriptase. Science 1988, 242(4882): 1168 1171.

9. Chew CB, Potter SJ, Wang B, Wang YM, Shaw CO, Dwyer DE, Saksena NK: Assessment of drug resistance mutations in plasma and peripheral blood mononuclear cells at different plasma viral loads in patients receiving HAART. J. of clin virol 2005, 33(3): 206-216.

10. Hirsch MS, Conway B, D'Aquila RT, Johnson VA, Brun-Vezinet F, Clotet B, Demeter LM, Hammer SM, Jacobsen DM, Kuritzkes DR, Loveday C, Mellors JW, Vella S, Richman DD: Antiretroviral drug resistance testing in adults with HIV infection: implications for clinical management. International AIDS Society--USA Panel. Jama 1998, 279(24): 1984-1991.

11. Yerly S, Rakik A, Kinloch-de-Loes S, Erb P, Vernazza P, Hirschel B, Perrin L: [Prevalence of transmission of zidovudine-resistant viruses in Switzerland. 1'Etude suisse de cohorte VIH]. Schweiz med Wochenschr 1996, 126(43): 1845-1848.

12. Hecht FM, Grant RM, Petropoulos CJ, Dillon B, Chesney MA, Tian H, Hellmann NS, Bandrapalli NI, Digilio L, Branson B, Kahn JO: Sexual transmission of an HIV-1 variant resistant to multiple reverse-transcriptase and protease inhibitors. $N$ Engl $j$ of med 1998, 339(5): 307-311.

13. Boucher CA, Cammack N, Schipper P, Schuurman $R$, Rouse P, Wainberg MA, Cameron JM: Highlevel resistance to $(-)$ enantiomeric 2'-deoxy-3'thiacytidine in vitro is due to one amino acid substitution in the catalytic site of human immunodeficiency virus type 1 reverse transcriptase. Antimicrobial agents and chemotherapy 1993, 37(10): 2231-2234.

14. Back NK, Nijhuis M, Keulen W, Boucher CA, Oude Essink BO, van Kuilenburg AB, van Gennip AH, Berkhout B: Reduced replication of 3TC-resistant HIV-1 variants in primary cells due to a processivity defect of the reverse transcriptase enzyme. The EMBO journal 1996, 15(15): 4040-4049.

15. Larder BA, Kemp SD, Harrigan PR: Potential mechanism for sustained antiretroviral efficacy of AZT-3TC combination therapy. Science 1995, 269(5224): 696-699.

16. Keulen W, Back NK, van Wijk A, Boucher CA, Berkhout B. Initial appearance of the 184Ile variant in lamivudine-treated patients is caused by the mutational bias of human immunodeficiency virus type 1 reverse transcriptase. J virol 1997, 71(4): 3346-3350.

17. Cheynier R, Gratton S, Vartanian JP, Meyerhans A, Wain-Hobson S: G --> A hypermutation does not result from polymerase chain reaction. AIDS research and human retroviruses 1997, 13(12): 985986.

18. Gunther S, Sommer G, Plikat U, Iwanska A, WainHobson S, Will H, Meyerhans A: Naturally occurring hepatitis $B$ virus genomes bearing the hallmarks of retroviral G-->A hypermutation. Virology 1997, 235(1): 104-108.

19. Khan S, Rai MA, Khanani MR, Khan MN, Ali SH: HIV-1 subtype A infection in a community of intravenous drug users in Pakistan. BMC infectious diseases 2006, 6: 164.

20. Yerly S, Kaiser L, Race E, Bru JP, Clavel F, Perrin L: Transmission of antiretroviral-drug-resistant HIV-1 variants. Lancet 1999, 354(9180): 729-733.

21. Jangam SR, Yamada DH, McFall SM, Kelso DM: Rapid, Point-of-Care Extraction of Human Immunodeficiency Virus Type 1 Proviral DNA from Whole Blood for Detection by Real-Time PCR. J Clin Microbiol 2009, 47(8): 2363-2368.

22. De Rossi A, Zanchetta M, Vitone F, Antonelli G, Bagnarelli P, Buonaguro L, Capobianchi MR, Clementi M, Abbate I, Canducci F, Monachetti A, Riva E, Rozera G, Scagnolari C, Tagliamonte M, Re MC: Quantitative HIV-1 proviral DNA detection: a multicentre analysis. The new microbiologica 2010, 33(4): 293-302.

23. Kandathil AJ, Kannangai R, Verghese VP, Pulimood SA, Rupali P, Sridharan G, Grant P, Pillay D, Abraham OC: Drug resistant mutations detected by genotypic drug resistance testing in patients failing therapy in clade C HIV-1 infected individuals from India. Ind $j$ med microbio 2009, 27(3): 231-236.

24. Miller V, Phillips A, Rottmann C, Staszewski S, Pauwels R, Hertogs K, de Bethune MP, Kemp SD, Bloor S, Harrigan PR, Larder BA: Dual resistance to zidovudine and lamivudine in patients treated with zidovudine-lamivudine combination therapy: association with therapy failure. The Journal of infectious diseases 1998, 177(6): 1521-1532. 
25. Wensing AM, Calvez V, Günthard HF, Johnson VA, Paredes R, Pillay D, Shafer RW, Richman DD: 2014 Update of the drug resistance mutations in HIV-1. Topics in Antiviral Medicine 2014, 22(3): 642650.

26. Paredes R, Marconi VC, Campbell TB, Kuritzkes DR: Systematic evaluation of allele-specific realtime PCR for the detection of minor HIV-1 variants with pol and env resistance mutations. Journal of virological methods 2007, 146(1-2): 136-146.

27. Frater AJ, Dunn DT, Beardall AJ, Ariyoshi K, Clarke JR, McClure MO, Weber JN: Comparative response of African HIV-1-infected individuals to highly active antiretroviral therapy. AIDS 2002, 16(8): 1139-1146.

28. Delaunay $C$, Brun-Vézinet $F$, Landman $R$, Collin $G$, Peytavin G, Trylesinski A, Flandre P, Miller M, Descamps D: Comparative Selection of the K65R and M184V/I Mutations in Human Immunodeficiency Virus Type 1-Infected Patients Enrolled in a Trial of First-Line TripleNucleoside Analog Therapy (Tonus IMEA 021). Journal of virology 2005, 79:9572-9578.

29. Hira SK, Panchal K, Parmar PA, Bhatia VP: High resistance to antiretroviral drugs: the Indian experience. International journal of STD \& AIDS 2004, 15(3): 173-177.

30. Sen S, Tripathy SP, Patil AA, Chimanpure VM, Paranjape RS: High prevalence of human immunodeficiency virus type 1 drug resistance mutations in antiretroviral treatmentexperienced patients from Pune, India. AIDS research and human retroviruses 2007, 23(10): 13031308.

31. Zaccarelli $M$, Perno CF, Forbici F, Cingolani A Liuzzi G, Bertoli A, Trotta MP, Bellocchi MC, Di Giambenedetto S, Tozzi V, Gori C, D'Arrigo R, De Longis P, Noto P, Girardi E, De Luca A, Antinori A: Using a database of HIV patients undergoing genotypic resistance test after HAART failure to understand the dynamics of M184V mutation. Antiviral therapy 2003, 8(1): 51-56. 